\title{
ANALISIS TINGKAT PEMAHAMAN MASYARAKAT PADA LEMBAGA KEUANGAN SYARIAH \\ (STUDI KASUS DI DESA KARDULUK KECAMATAN PRAGAAN KABUPATEN SUMENEP)
}

\author{
Ubaidullah Muayyad'), Halimi Al Mahdi'2), Ahmad Wahidi' ${ }^{3}$ ) \\ Institut Ilmu Keislaman Annuqayah Guluk-Guluk Sumenep \\ ${ }^{1)}$ ubaid.asthow91@gmail.com, 2)halimialmahdi69@gmail.com, ${ }^{3)}$ dhaidara999@gmail.com
}

\begin{abstract}
Abstrak. Penelitian ini muncul berdasarkan perhatian penulis terhadap Desa Karduluk Kecamatan Pragaan yang notabennya beragama islam dan mayoritas orang berpendidikan, akan tetapi dalam pemahamannya pada lembaga keuangan syariah lemah atau minim. Maka dari itu peneliti memperoleh beberapa rumusan masalah yaitu:1. Apa saja lembaga keuangan syariah yang diketahui oleh masyarakat desa Karduluk? 2. Bagaimana tingkat pemahaman masyarakat desa Karduluk pada lembaga keuangan syariah? 3. Faktor apa saja yang mempengaruhi tingkat pemahaman masyarakat desa Karduluk untuk melakukan transaksi di lembaga keuangan syariah ?. Jenis penelitian menggunakan metode kualitatif. Dan teknik pengumpulan datanya menggunakan wawancara, Observasi, dan dokumentasi. Subjek penelitian ini adalah Masyarakat Desa Karduluk Kecamatan Pragaan Kabupaten Sumenep. Sementara untuk analisa datanya menggunakan penyajian data, reduksi data, dan penarikan kesimpulan. Hasil penelitian ini menunjukkan bahwa pemahaman masyarakat Desa Karduluk tentang lembaga kauangan syariah masih kurang hal ini dibuktikan bahwa masih banyak masyarakat karduluk yang belum tahu apa itu lembaga keuangan syariah, salah satu bukti yang terjadi di lapangan adalah masyarakat karduluk banyak yang melakukan pembiayaan atau bertransaksi dengan lembaga keuangan non syariah. Selain memang tidak paham pada LKS (lembaga keuangan syariah) masyarakat karduluk juga beranggapan bahwa ketika melakukan transaksi di LKS (lembaga keuangan syariah) prosesnya terlalu sulit, biayanya mahal dan jangkauannya jauh.
\end{abstract}

Kata Kunci: Pemahaman, Masyarakat, Anggapan, Lembaga Keuangan Syariah.

Abstact. This research emerged based on the author's attention to Karduluk Village, Pragaan District, which incidentally is Muslim and the majority of people are educated, but in their understanding of Islamic financial institutions it is weak or minimal. Therefore, the researchers obtained several problem formulations, namely: 1 . What are the Islamic financial institutions that are known by the people of Karduluk village? 2. What is the level of understanding of the Karduluk village community in Islamic financial institutions? 3. What factors affect the level of understanding of the Karduluk village community to conduct transactions at Islamic financial institutions?. This type of research uses qualitative methods. And data collection techniques using interviews, observation, and documentation. The subject of this research is the Karduluk Village Community, Pragaan District, Sumenep Regency. Meanwhile, for data analysis using data presentation, data reduction, and drawing conclusions. The results of this study indicate that the understanding of the people of Karduluk Village about sharia financial 
institutions is still lacking, it is proven that there are still many karduluk people who do not know what sharia financial institutions are, one of the evidences that occurs in the field is that many karduluk people do financing or transact with institutions non-sharia finance. Apart from not really understanding the LKS, the Karduluk community also thought that when making transactions at LKS the process was too difficult, the costs were expensive and the reach was far.

Keywords: Understanding, Society, Assumptions, Islamic Financial Institutions

\section{PENDAHULUAN}

Sebelum peneliti membahas lebih jauh tentang lembag keuangan syariah, peneliti akan terlebih dahulu menjelaskan definisi lembaga keuangan (Finansial Institution). Lembaga keuangan adalah suatu perusahaan yang bergerak dibidang jasa keuangan yang pekerjaannya adalah menghimpunan dana masyarakat atau jasa-jasa keuangan lainnya. Dikutip dari SK Menkeu RI No. 792 Tahun 1990, bahwa didalamnya mengatakan lembaga keuangan syariah adalah suatu badan yang kegiatannya adalah melakukan penghimpunan dan menyalurkan dana kepada masyarakat terutama bagi yang sangat membutuhkan dana tersebut.

Lembaga keuangan syariah adalah suatu perusahaan yang usahanya bergerak di bidang jasa keuangan berdasarkan prinsip-prinsip syariah, yaitu menghilangkan unsur-unsur yang dilarang dalam islam, kemuadian menggantikannya dengan akad-akad tradisional islam atau yang biasa kita kenal dengan prinsip syariah. ${ }^{1}$

Umat islam adalah perintis pertama kali di lembaga keungan syariah yaitu denhgan mendirikan sebuah organisasi yang organisasi tersebut diberi nama OKI (Organisasi Konverensi Islam) di Benghazi, Libya pada bulan Maret 1973. Di dalam organisasi itu terbentuklah sebuah lembaga yang diberi nama bank pembangunan islam atau Islamic Development Bank (IDB) dengan modal awal 2 Milyar Dinar Islam. IDB adalah faktor utama yang mempengaruhi negaranegara islam untuk termotifasi dan juga mendirikan lembaga keuangan syariah dalam bentuk bank-bank islam. Salah satunya adalah Negara Indonesia yang mendirikan bank islam pada tahun 1992 yang diberi nama Bank Muamalat Indonesia (BMI), setelah BMI banyak yang bermunculan lembaga-lembaga perbankan lain yang menggunakan prinsip syariah.

Tujuan utama didirikanya lembaga keuangan islam adalah semata-mata untuk menunaikan printah Allah dalam bidang ekonomi dan muamalat, serta membebaskan mayarakat islam dalam

${ }^{1}$ Dr. Mardani Aspek Hukum Lembaga Keuangan Syariah di Indonesia, (Jakata: Kencana, Cet.1,2017),h. 01 
melakukan kegiatan-kegiatan yang dilarang oleh agama islam. Di Indonesia tujannya adalah untuk memberikan pelayanan kepada masyrakat indoneisa secara umum, bukan hanya kepada umat muslim saja tetapi juga seluruh komponen bangsa dengan alasan jika menggunakan sistem riba maka sangat jauh dari nilai-nilai keadilan. ${ }^{2}$

Penelitian ini mengambil satu masalah yang terjadi di desa karduluk, kecamatan pragaan, kabupaten sumenep. Yang mana pada masalah ini peneliti akan menganalisa tingkat pemahaman masyarakat desa karduluk terhadap lembaga keuangan syariah. Berdasarkan survei yang dilakukan peneliti melihat desa karduluk ini cukup jauh dari lembga keuangan syariah disana itu tidak ada sama sekali lembaga keuangan syariah yang berdiri di dekat desa ataupun di desa karduluk itu sendiri. Tetapi potensi untuk bisa bertransaksi di lembaga keuangan syariah peluangnya masih cukup besar dikarenakan lembaga keuangan syariah masih ada di satu kecamatan pragaan di desa prenduan, yaitu BPRS,Pegadaian Syariah, BMT NU dan Koprasi yang terletak di desa prenduan kecamatan pragaan. Selain itu masyarakat desa karduluk rata-rata beragama islam. Tetapi dilihat dari pemahaman masyarakat terhadap lembaga keuangan syariah sangatlah rendah bahkan ada sebagian masyarakat desa karduluk tidak tahu sama sekali terhadap lembaga keuangan syariah, mereka hanya tahu lembaga non syariah seperti, Bank Mandiri, Bank BRI dan Bank lainnya yang bukan berlebel syariah. Mereka melakukan transaksi dengan bank-bank di atas bukan lantas karna mereka paham terhadap bank akan tetapi karena mereka sering bertransaksi dengan bank tersebut.

Hasil wawancara peneliti dengan Bapak Wahdi yang memiliki usaha toko mebel kampung Dhurbuken desa Karduluk kecamatan pragaaan kabupaten sumenep, beliau pernah melakukan transaksi dengan lembaga keuangan syariah yaitu dengan BMT NU, namun beliau hanya menyimpannya saja. Ketika saya tanya tentang apa itu lembaga keuangan syariah, Bapak. Wahdi menjawa beliau tidak begitu paham dengan lembaga keuangan syariah, tidak tahu produkproduk di dalamnya seperti apa. ${ }^{3}$ Sedangakan hasil wawancara dengan Bapak. Iskandar yang beralamatkan kampung Dunggaddung desa Karduluk mengatakan bahwa beliau hanya mempunyai kartu ATM bank konvensional alasan beliau tidak menggunakan lembaga keuangan syariah yaitu dengan cara bertransaksi dengan bank syariah karna jika buat ATM yang syariah

\footnotetext{
${ }^{2}$ Budi Kolestiawan, Tentang lembaga Keuangan Syariah dalam Menghadapi Masyarakat Ekonomi ASEAN, (Jurnal Ekonomi dan Perbankan Syariah Institut Agama Islam Negri Tulungagung,Vol 8 No1 2017)

3 Wahdi, wawancara, 16 september 2021
} 


\section{AL-IOTISHOD \\ Jurnal Ehonomi Suariah}

Institut Agama Islam Sunan Kalijogo Malang P-ISSN 2715-7725 E-ISSN 2721-9496

Volume 3 Nomor 2 Desember 2021

ditempatnya cara aksesnya tidak ada dan jauh dan jika mengambil di ATM konvensional maka akan dikenai biaya besar, jadi Bapak Iskandar tidak mau ambil pusing dengan hal itu." 4

Hasil wawancara yang dilakukan peneliti di desa karduluk kecamatan pragaan kabupaten sumenep masih ada masyarakat yang kurang begitu faham terhadap lembaga keuangan syariah, bahkan masih terdapat dari masyarakat karduluk yang tidak tahu produk-produk di dalamnya seperti apa meskipun masyarakat tersebut pernah melakukan transaksi dengan lembaga keuangan syariah. Meskipun sudah bisa dikatakan ada lembaga keuangan syariah meskipun tidak di desa Karduluk itu sendiri melainkan di desa Prenduan apalagi mayoritas penduduknya muslim tidak menutup kemungkinan untuk melakukan transaksi dengan lembaga keuangan syariah, namun di desa Karduluk tidak ada pengaruh besar, bahkan mayoritas penduduknya tidak paham apa itu lembaga keuangan syariah (LKS). Berdasarkan latar belakang di atas, peneliti ingin mengetahui dan melakukan penelitian terhadap pemahaman masyrakat tentang lembaga keungan syariah (LKS) lebih mendalam lagi dengan judul penelitian "Analisis Tingkat Pemahaman Masyarakat pada Lembaga Keuangan Syariah. (studi di Desa Karduluk Kecamatan Pragaan Kabupaten Sumenep)".

\section{LITERATUR REVIEW}

\section{A. Penelitian Terdahulu}

Dalam penulisan karya ilmiah disini peniliti akan kaitkan dengan beberapa karya ilmiah terdahulu, sehingga nanti akan ditemukan titik perbedaan dan persamaan dari karya ilmiah diatas, Adapun karya ilmiah yang penulis maksud adalah sebagi berikut:

Skripsi Zaira Khairina, Jurusan Perbankan Syariah dengan judul: Tingkat pengetahuan masyarakat tentang produk perbankan syariah (studi kasus kecamatan peukan bada kabupaten aceh besar tahun 2019/2020). Skripsi ini membahas tentang bagaimana pengetahuan masyarakat terhadap produk penghimpunan dana perbankan syariah, produk penyaluran perbankan syariah dan produk jasa pada perbankan syariah serta apa tujuan dan manfaatnya. Adapun hasil dari penelitian ini adalah masyarakat peukan kabupaten aceh besar sudah mengetahui keberadaan bank syariah namun mereka tidak tahu sepenuhnya tentang produk-

\footnotetext{
${ }^{4}$ Iskandar, wawancara, 16 september 2021
} 
produk perbankan syariah. Artinya pengetahuan masyarakat peukan kabupaten aceh besar masih digolongkan redah dalam mengetahui produk-produk dalam perbankan syariah. ${ }^{5}$

Skripsi Angga Dwi Saputra, Jurusan Ekonomi Syariah dengan judul : Analisis Pengaruh Pendidikan dan Faktor sosial Terhadap Pengetahuan Masyarakat Tentang Bank Syariah (studi kasus di Dusun Pundung Wukirsari Imogiri Bantul 2016/2017). Skripsi ini membahas tentang seberapa besar pengaruh pendidikan dan faktor sosial terhadap pengetahuan pengetahuan masyarakat pada perbankan syariah dan apa tujuan dan manfaatnya. Hasil dari penelitian ini memperoleh bahwa pendidikan itu berpengaruh positif terhadap pengetahuan masyarakat tentang bank syariah, sedangkan faktor sosial itu tidak berpengaruh terhadap bank syariah. Adapun hasil dari kedua-duanya pendidikan dengan faktor sosial itu berpengaruh terhadap pengetahuan masyarakat tentang bank syariah. ${ }^{6}$

Jadi dari tinjauan pustaka diatas dapat ditemukan titik perbedaan dan persamaan penelitian yang peneliti teliti. Dari titik persamaannya adalah sama-sama membahas tentang pemahaman masyarakat tentang bank syariah. Dan perbedaannya adalah terletak pada objek dari pemahaman tersebut. Salah satunya adalah produk dalam bank syariah, faktor pendidikan dan sosial yang mempengaruhi pemahaman masyarakat. Sedangkan dalam penelitian ini lebih fokus kepada lembaga keuangan syariah itu sendiri. Apa saja lembaga keuangan syariah dan bagaimana tingkat pemahaman masyarakat pada lembaga keuangan syariah.

\section{B. Pemahaman Masyarakat}

1. Pemahaman

Dalam buku yang ditulis oleh Berns dan Erickson, arti pemahaman adalah merupakan persyaratan mutlak untuk mencapai kemampuan kognitif yang tinggi, analisis, aplikasi, sintesis dan evaluasi. Namun dalam penelitian ini peneliti menggunakan teori pemahaman hasil dari revisi taksonomi bloom, dimana Anderson dan Krathwohl mengungkapkan tujuh kategori proses kognitif pemahaman diantaranya: memberikan contoh (exemplifying),menafsirkan (interpreting), meringkas (summarizing),mengklarifikasi (classifying),membandingkan (comparing), menarik inferensi (inferring), dan menjelaskan (explaining). ${ }^{7}$

\section{Lembaga Keuangan Syariah}

${ }^{5}$ Zaira Khairina, Tingkat pengetahuan masyarakat tentang produk perbankan syariah (studi kasus kecamatan peukan bada kabupaten aceh besar tahun 2019/2020). (Banda Aceh; 2019).

${ }^{6}$ Angga Dwi Saputra, Analisis Pengaruh Pendidikan dan Faktor Sosial terhadap Pengetahuan Masyarakat tentang Bank Syariah. (studi kasus di Dusun Pundung Wukirsari Imogiri Bantul 2016/2017).(Yogyakarta : 2016).

7 Tingkat pemahaman konsep .https://eurekapebdidikan.com/tingkat-pemahaman-konsep.2021 
Lembaga keuangan syariah adalah lembaga yang kegiayan uatamanya adalah menghimpun dan menyalurkan dana, dengan tujuan agar mendapat keuntungan. Fungsi utama pada lembaga keuangan adalah sebagai perantara pihak-pihak yang membutuhkan modal dengan pihak-pihak yang memiliki dana. Dalam islam hal yang digunakan adalah konsep melalui akad-akad bagi hasil, untuk memenuhi kebutuhan permodalan, dan akad jual beli, sebagai kebutuhan pembiayaan. Bank dalam islam tidak menggunakan metode pinjam-meminjam uang dalam bentuk kegiatan komersial, karena jika pinjam-meminjam nanti diikat janji atau memberikan imbalan maka hal tersebut termasuk riba. Oleh karena itu oprasional dalam lembaga keuangan syariah khususnya di bank syariah menggunakan prinsip-prinsip ; Bagi Hasil, Jual Beli, Sewa, Qord, Titipan dan Jasa. ${ }^{8}$

\section{METODE PENELITIAN}

Jenis penelitian yang peneliti gunakan dalam mendeskripsikan masalah yang terjadi menggunakan penelitian kualitatif, yaitu dengan cara wawancara, pengamatan dan menelaah dokumen. Dengan metode kualitatif ini peneliti lebih mudah dalam menyesuaikan dengan keadaan lingkungan atau objek yang akan diteliti. Metode ini menyajikan secara langsung hakikat hubungan peneliti dengan responden dan metode ini lebih peka dan lebih dapat menyesuaikan diri dengan keadaan sekitar atau objek yang akan diteliti. ${ }^{9}$

Lokasi dari penelitian ini bertempat di desa Karduluk, Kecamatan Pragaan, Kabupaten Sumenep. Fokus dari penelitian ini tentang tingkat pemahaman masyarakat karduluk pada lembaga keuangan syariah. Dalam tahap pengumpulan data di lapangan, peneliti menggunakan beberapa instrument. Yang pertama, teknis observasi sebagai metode untuk mengamati keberadaa masyarakat Karduluk dalam memahami lembaga keuangan syariah. Kedua, terknik interview dilakukan untuk menggali data dari informan secara lebih mendalam, salah satunya kepada tokoh masyarakat dan tentunya juga kepada masyarakat itu sendiri.

Metode analisis data yang digunakan adalah analisi secara mendalam untuk mengelola data dari hasil wawancara dan observasi, kemudian peneliti memaparkan hasil tersebut dalam bentuk reduksi data, bahan emperik dan menarik kesimpulan.

\footnotetext{
8 Matnin, SH.I, M,EI dan Aang Kunaifi,SE, M.EI, Manajemen Lembaga Keuangan dan Bisnis Islam, Duta Media Pubilshing 2017. Hlm.12

${ }^{9}$ Adi Kusuma dan Ahmad Mustamil Khaoiron, Metode penelitian kualitatif penerbit : lembaga pendidikan sukarno pressindo kota semarang 2019. Hlm.11
} 


\section{HASIL DAN PEMBAHASAN}

Lembaga keuangan syariah adalah sistem yang menjadi pengatur keuangan, yang mana sistem tersebut menjadi sebab adanaya transaksi antara pihak yang membutuhkan dana dengan pihak yang memiliki kelebihan dana melalui produk dan jasa keuangan yang sesuai dengan prinsip-prinsip syariah. Prinsip syariah yang dimaksud adalah berdasarkan Al-Quran dan Hadist. ${ }^{10}$

Dalam lembaga keuangan syariah sudah jelas bahwa didalamnya terdapat jamainan mengenai kehalalan pemutaran uangnya dengan bisnis yang sesuai dengan syariah. Sehingga, perlu kiranya untuk memberikan pemahaman kepada masyarakat Desa Karduluk agar tidak salah dalam menilai lembaga keuangan syariah. Ada beberapa pembahasan yang akan peneliti uraikan dalam tulisan ini, antara lain:

1. Lembaga Keuangan Syariah yang diketahui masyarakat Karduluk, Kecamatan Pragaan, Kabupaten Sumenep.

Penelitian ini dilakukan dengan mewawancarai masyarakat Desa Karduluk, Kecamatan Pragaan, Kabupaten Sumenep, yang mayoritas penduduknya memiliki usaha mebel dan kemungkinan besar banyak yang bertransaksi dengan lembaga keuangan, khususnya lembaga keuangan syariah. Dari pendapat masyarakat terkait dengan lembaga keuangan syariah dapat diketahui lembaga keuangan syariah apa yang ada di Desa Karduluk.

Berdasarkan hasil wawancara yang dilakukan peneliti terhadap 10 masyarakat Desa Karduluk, Kecamatan Pragaan, Kabupaten Sumenep sebagai narasumber dari peneliti menunjukkan bahwa dari seluruh narasumber yang tahu terhadap lembaga keuangn syariah khususnya bank syariah dan juga usaha mikro kecil syariah hanya $2 \%$. Masyarakat hanya sekedar tahu tetapi mereka tidak mau bertransaksi dengan lembaga keuangan syariah khususnya bank syariah dan juga usaha mikro syariah yang ada di Desa Karduluk. Faktor utama yang mempengaruhi atas ketidak tahuan mereka pada lembaga keuangan syariah adalah lembaga keuangan yang ada di Desa Karduluk jarang hanya ada satu yaitu Koprasi, meskipun ada BPRS dan juga Pegadaian Syariah itu aksesnya jauh tempatnya di Desa Prenduan tetapi masih satu Kecamatan yaitu, Pragaan. yang kedua adalah minimnya informasi atau sosialisasi tentang lembaga keuangan syariah dari pihak terkait. Seperti halnya dari BPRS, Pegadaian Syariah atau lembaga keuangan syariah yang lain.

10 Dr. Andri Soemitra, M.A. Bank dan lembaga keuangan syariah. Cet ke 5. Penerbit Kencana, 2009. Hlm. 16 
2. Tingkat Pemahaman Masyarakat Karduluk pada Lembaga Keuangan Syariah Kecamatan Pragaan, Kabupaten Sumenep.

Pemahaman masyarakat Desa Karduluk mengenai lembaga keuangan syariah berbanding lurus dengan minat menabung masyarakat Karduluk. Hal ini diketahu dari sedikitnya masyarakat Karduluk yang mau menabung di Perbankan Syariah. Dari 10 orang narasumber yang memiliki tabungan, hanya 2 sampai 3 orang yang menabung di perbankan syariah sisanya menabung di bank konvensional atau lembaga keuangan non syariah karena kurang pahamanya masyarakat terhadap lembaga keuangan syariah. Perbedaan yang paling signifikan dalam lembaga keuangan syariah dengan lembaga keungan non syariah terletak pada jenis investasinya, contohnya di lembaga keuangan syariah dari sisi perbankan syariahnya. Di perbankan syariah itu tidak ada yang namanya bunga yang ada bagi hasil, sedangkan di bank konvensional itu ada bunga, yang hal tersebut jika di dalam agama islam dilarang. Namun menurut masyarakat karduluk mereka tidak peduli dengan sistem yang seperti itu, yang penting uang mereka aman di bank, baik itu bank syariah ataupun bank konvensional.

Maka perlu kiranya pihak lembaga keuangan syariah khususnya perbankan syariah untuk memberikan pencerahan atau pemahaman terkait transaksi yang benar dan transaksi yang tidak benar atau transaksi yang tidak sesuai dengan syariah islam. Jika ditinjau dari segi produk, semua produk yang ada di bank syariah itu ada di bank konvensional perbedaanya hanya dalam istilah nama dan sistem. Oleh karena itu agar masyarakat juga paham dan tertarik untuk melakukan transaksi dengan lembaga keungan syariah khususnya di perbankan syariah maka pihak perbankan syariah melakukan kerjasama dengan para tokoh ulama' seperti kiyai dan juga guru dan dosen yang juga berperan penting dalam masyarakat, selain itu pihak perbankan syariah juga meningkatkan pelayanan dengan fasilitas-fasilitas yang dimiliki bank konvensioanal juga ada di perbankan syariah, sehingga nasabah perbankan syariah mendapatkan kemudahan dalam bertransaksi, Seperti ATM bank syariah.

3. Faktor yang mempengaruhi tingkat pemahaman masyarkat Desa Karduluk untuk melakukan transaksi di Lembaga Keuangan Syariah.

Pemahaman masyarakat desa Karduluk bisa disebabkan oleh beberapa faktor, baik faktor internal ataupun eksternal. Dari faktor internal, Secara garis besar dilihat dari fisiknya dan seluruh anggota tubuhnya masyarakat Karduluk terlihat normal, jadi kemungkinan besar dalam memahami sesuatu masyarakat Karduluk juga baik. Tidak hanya itu, keadaan psikis dan 
psikomotor masyarakat Desa Karduluk juga terlihat normal.Hal tersebut bisa dibuktikan responden pandai dalam mengajukan pertanyaan ataupun dalam menjawab pertanyaanpertanyaan. Adapun foktor eksternalnya setiap masyarakat Desa Karduluk mempunyai perbedaan, diantranya adalah faktor pendidikan, ekonomi dan hubungan sosial. ${ }^{11}$

Adapun beberapa faktor Eksternal tersebut, antara lain :

a. Pemahaman masyarakat Desa Karduluk berdasarkan Faktor Pendidikan.

Pemahaman masyarakat Desa Karduluk juga di pengaruhi oleh faktor eksternal, seperti faktor eksternal dalam segi pendidikan, dimana semakin tinggi pendidikan yang dicapai seseorang maka dalam menangkap sebuah informasi akan semakain rasional. Dari fakta lapangan yang terjadi rata-rata masyarakat Desa Karduluk pencapaian di bidang pendidikan cukup tinggi, banyak yang sudah mencapai tingkat stara-1, namun hal tersebut belum menjadi jaminan akan pahamanya terhadap lembaga keuangan syariah. Hal itu terbukti dari banyaknya responden yang tingkat pendidikannya tidak selesai namun paham terhadap lembaga keuangan syariah.

b. Pemahaman Masyarakat Desa Karduluk berdasarkan Faktor Ekonomi.

Selain faktor pendidikan ada juga faktor ekonomi dimana penelitian ini para informan memiliki latar belakang ekonomi yang berbeda-beda, ada masyarakat yang mempunyai ekonomi yang tinggi yang bisa mencukupi kebutuhan primer maupun skundernya, ada juga masyarakat yang keadaan ekonominya rendah. Masyarakat yang memiliki ekonomi yang rendah akan takut jika berhunbungan dengan lembaga keuangan, baik itu syariah ataupun non syariah. Apalagi untuk memahami lembaga keuangan syariah.

c. Pemahaman Masyarakat Desa Karduluk berdasarkan Faktor Hubungan Sosial.

Selain pendidikan, dan ekonomi adapun faktor eksternal yang lain adalah faaktor eksternal dari segi hubungan sosial, masyarakat yang mempunyai hubungan sosial yang bagus anatara masyarakat yang satu dengan masyarakat yang lain, maka akan semakin mudah dalam menagkap informasi- informasi yang datang. Berdasarkan fakta lapangan yang terjadi, peneliti melihat dari segi hubungan masyarakat sangat bagus karna rata-rata masyarakat Desa Karduluk memiliki usaha, jadi kemungkinan untuk melakukan transaksi dengan lembaga keuangan itu sangat besar. Maka perlu kiranya dari pihak lembaga keuangan syariah melakukan sosialisasi dengan meningkatkan kesadaran masyarakat tentang lembaga keuangan syariah yang

\footnotetext{
11 Matnin, SH.I, M,EI dan Aang Kunaifi,SE, M.EI, Manajemen Lembaga Keuangan dan Bisnis Islam, Duta Media
} Pubilshing 2017. Hlm.12 
membawa perubahan kepada perkembangan ekonomi Desa Karduluk yang sesuai dengan prinsip-prisip syariah.

\section{KESIMPULAN}

Berdasarkan penelitian dari hasil wawancara peneliti dapat menyimpulkan, bahwa tingkat pemahaman masyarakat Desa Karduluk, Kecamatan Pragaan, Kabupaten Sumenep tergolong lemah, hal ini terjadi ketika peneliti mewawancarai sebagaian dari masyarakat Desa karduluk, para informan tidak mengetahu keberadaan lembaga keuangan syariah dan bagaimana mekanisme didalamnya. Selain itu dapat disimpulkan bahwa masyarakat Desa Karduluk minim sekali informasi ataupun sosialisai dari pihak lembaga keuangan syariah, sehingga tidak begitu paham perbedaan lembaga keuangan syariah dan non syariah. Hasil dari wawancara tersebut bisa dikatagorikan pemahaman tingkat kedua, yaitu pemahaman penafsiran. Masyarakat Desa karduluk bisa digolongkan paham meskipun tingkat pemahamannya rendah. Hal ini juga sangat penting bagi peneliti untuk menyampaikan bahwa masyarakat Desa Karduluk tidak menggunakan atau bertransaksi di lembaga keuangan syariah dikarenakan aksesnya jauh, tidak seperti lembaga non syariah yang ATM nya bisa kita ambil dimana saja. Dan yang terakhir yang mempengaruhi tingkat pemahaman masyarakat Desa Karduluk pada lembaga keuangan syariah adalah faktor pendidikan, ekonomi dan hubungan sosial, jika ketiganya teraplikasi dengan baik maka pemahaman masyarakat pada lembaga keuangan syariah akan tinggi, begitupun sebaliknya. 


\section{DAFTAR PUSTAKA}

Dr. Mardani Aspek Hukum Lembaga Keuangan Syariah di Indonesia, (Jakata: Kencana, Cet.1,2017).

Budi Kolestiawan, Tentang lembaga Keuangan Syariah dalam Menghadapi Masyarakat Ekonomi ASEAN, (Jurnal Ekonomi dan Perbankan Syariah Institut Agama Islam Negri Tulungagung, 2017).

Zaira Khairina, Tingkat pengetahuan masyarakat tentang produk perbankan syariah (studi kasus kecamatan peukan bada kabupaten aceh besar tahun 2019/2020). (Banda Aceh; 2019).

Angga Dwi Saputra, Analisis Pengaruh Pendidikan dan Faktor Sosial terhadap Pengetahuan Masyarakat tentang Bank Syariah. (studi kasus di Dusun Pundung Wukirsari Imogiri Bantul 2016/2017).(Yogyakarta : 2016).

Adi Kusuma dan Ahmad Mustamil Khaoiron, Metode penelitian kualitatif penerbit : lembaga pendidikan sukarno pressindo kota semarang 2019.

Dr. Andri Soemitra, M.A. Bank dan lembaga keuangan syariah. Cet ke 5. Penerbit Kencana, 2009.

Matnin, SH.I, M,EI dan Aang Kunaifi,SE, M.EI, Manajemen Lembaga Keuangan dan Bisnis Islam, Duta Media Pubilshing 2017. 